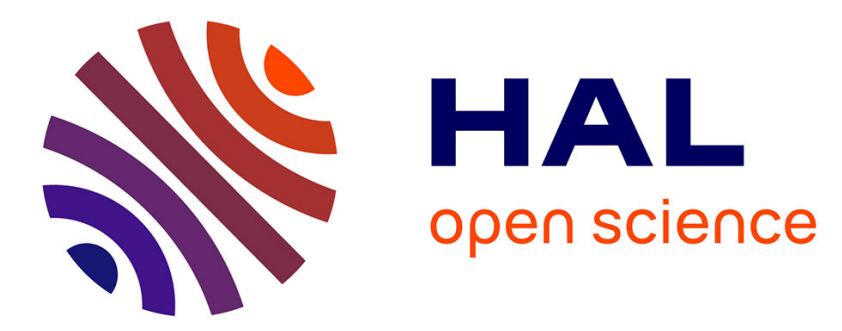

\title{
Effect of cultivation practices on cadmium concentration in rice grain
}

\author{
Ilenia Cattani, Marco Romani, Raffaella Boccelli
}

\section{To cite this version:}

Ilenia Cattani, Marco Romani, Raffaella Boccelli. Effect of cultivation practices on cadmium concentration in rice grain. Agronomy for Sustainable Development, 2008, 28 (2), pp.265-271. hal-00886419

\section{HAL Id: hal-00886419 \\ https://hal.science/hal-00886419}

Submitted on 1 Jan 2008

HAL is a multi-disciplinary open access archive for the deposit and dissemination of scientific research documents, whether they are published or not. The documents may come from teaching and research institutions in France or abroad, or from public or private research centers.
L'archive ouverte pluridisciplinaire HAL, est destinée au dépôt et à la diffusion de documents scientifiques de niveau recherche, publiés ou non, émanant des établissements d'enseignement et de recherche français ou étrangers, des laboratoires publics ou privés. 


\title{
Effect of cultivation practices on cadmium concentration in rice grain
}

\author{
Ilenia CATtAnI $^{1 *}$, Marco Romani $^{2}$, Raffaella Boccelli ${ }^{1}$ \\ ${ }^{1}$ Istituto di Chimica Agraria ed Ambientale, sezione Vegetale - Università Cattolica del Sacro Cuore di Piacenza, Via Milano, 24- 26100 Cremona, Italy \\ ${ }^{2}$ Ente Nazionale Risi, Centro Ricerche sul Riso, Strada per Ceretto, 4- 27030 Castello d'Agogna (PV), Italy
}

(Accepted 26 July 2007)

\begin{abstract}
Cadmium (Cd) is one of the most toxic heavy metals, polluting the general environment. The application of sewage sludge, wastewaters and Cd-containing fertilizers causes an increase in $\mathrm{Cd}$ content in agricultural soils. Cd is easily taken up by plants and then enters the food chain, resulting in a serious health issue for humans. There is increasing concern regarding the occurrence of cadmium in rice, not only in the rice-growing areas of the Far East, but also in Europe. In this work we highlighted that, even when the agricultural soil is unpolluted and the concentration of $\mathrm{Cd}$ is low, e.g. $0.96 \mathrm{mg} \mathrm{kg}^{-1}$, the $\mathrm{Cd}$ content of rice may still exceed the regulatory limit of $0.2 \mathrm{mg} \mathrm{kg} \mathrm{kg}^{-1}$. To reduce the uptake of $\mathrm{Cd}$ by rice, paddy-field flooding and soil amendment with lime and compost were tested in a field trial during 2003 and 2004 in Rosate, near Milan, Italy. We found that submersion was the main factor decreasing the Cd concentration in rice grain, producing maximum concentrations of $0.14 \mathrm{mg} \mathrm{kg}^{-1}$ in 2003 and $0.06 \mathrm{mg} \mathrm{kg}^{-1}$ in 2004 . By comparison, Cd concentrations was at least two times higher for rice cultivated by irrigation only. Moreover, the addition of lime decreased the Cd concentration of rice by about $25 \%$ versus control under dry conditions. Lime addition thus appears to be a promising technique to reduce the bioavailability of soil $\mathrm{Cd}$ and minimize $\mathrm{Cd}$ concentrations in the produced rice. In contrast, the application of compost alone does not produced a significant effect. Differences in uptake over the years, with concentrations up to $40 \%$ lower in 2004 , can be explained by differences in transpiration. These results shows that the influence of climatic conditions on Cd uptake in plants should not be underestimated. Such agronomic information represents a very helpful tool for rice growers, in particular in the case of cultivation of Cd-polluted soils and production of Cd-contaminated rice grain.
\end{abstract}

paddy field / rice / water management / fertilizers

\section{INTRODUCTION}

Cadmium is one of the most toxic heavy metals reaching the food chain (Adriano, 2001) without being essential for plant function. Cadmium appears to be absorbed passively, translocated freely and is generally strongly assimilated by crops (Liu et al., 2003). Cadmium distribution between plant parts varies among plant species. For example, graminaceous and leguminous plants accumulate more cadmium in the aerian apical organs than leafy vegetables, such as lettuce and cabbage (Grant et al., 1999). Cadmium in soils, readily taken up and translocated by plants, is not phytotoxic at concentrations found in crops but this uptake can significantly increase human exposure (Adriano, 2001). There is increasing concern about the effect of $\mathrm{Cd}$ on human health. It is well known that rice-growing areas in the Far East are characterized by an irrefutable relationship between $\mathrm{Cd}$ exposure due to long-term rice consumption - rice is the staple food in these areas- and human diseases, such as renal dysfunction and Itai-Itai disease (Simmons et al., 2005). Some authors (Welch and Norwell,

* Corresponding author: ilenia.cattani@unicatt.it
1999) report that rice plants absorb Cd at a higher rate than water and concentrate it into tissues from the nutrient solution. The European limit for the concentration of $\mathrm{Cd}$ in rice grain is $0.2 \mathrm{mg} \mathrm{kg}^{-1}$ (Council regulation, 2001) and a lower limit in foodstuffs - particularly in baby food - is suggested. It has been established that cadmium-rich soils generally produce cadmium-rich foods (Suzuki et al., 1988). Consequently, information on trace element intake from different sources is useful for the prevention and control of diseases that are caused by mineral intake. Cadmium in soils may be atmospheric, geological or agricultural in origin, such as wastewaters, pesticides, fertilizers (Gimeno-Garcìa et al., 1996; Lugon-Moulina et al., 2006) or sewage sludge utilization (McBride, 1995). The agricultural soil solution typically contains $\mathrm{Cd}$ at a concentration of 0.1 to $4.7 \mu \mathrm{g} \mathrm{L}^{-1}$ (John et al., 1972), but soil factors such as $\mathrm{pH}$, organic matter content, cation exchange capacity, clay content, and the presence of microorganisms and other ions may play a role in the solubilization and mobilization of Cd (Chanmugathas and Bollag, 1987). Technologies to minimize the likelihood of $\mathrm{Cd}$ reaching the food chain are primarily aimed at reducing its uptake by plants and animals. Chemical 
Table I. Selected properties of soil collected from the experimental field (mean of 48 replicates). CEC: cation exchange capacity, OM: organic matter, DTPA: diethylenetriaminepentaacetate, Tot: total, SD: standard deviation.

\begin{tabular}{lcccccccc}
\hline $\begin{array}{c}\text { S kg-1 }) \\
\left(\mathrm{g} \mathrm{kg}^{-1}\right)\end{array}$ & $\begin{array}{c}\text { Silt } \\
\left(\mathrm{g} \mathrm{kg}^{-1}\right)\end{array}$ & Clay & $\begin{array}{c}\mathrm{pH} \\
\left(\mathrm{cmol}^{+} \mathrm{kg}^{-1}\right)\end{array}$ & $\begin{array}{c}\mathrm{CEC} \\
\left(\mathrm{g} \mathrm{kg}^{-1}\right)\end{array}$ & $\begin{array}{c}\mathrm{OM} \\
\left(\mathrm{mg} \mathrm{kg}^{-1}\right)\end{array}$ & $\begin{array}{c}\mathrm{Cd}_{\text {DTPA }} \\
\left(\mathrm{mg} \mathrm{kg}^{-1}\right)\end{array}$ & $\mathrm{Cd}_{\text {tot }}$ \\
\hline mean & 512 & 376 & 112 & 6.21 & 14.0 & 2.59 & 0.151 & 0.96 \\
$\mathrm{SD}$ & 93 & 110 & 32 & 0.16 & 2.6 & 0.19 & 0.032 & 0.16 \\
\hline
\end{tabular}

Table II. Cd distribution through the soil profile (mean of four replicates, $\mathrm{mg} \mathrm{kg}^{-1}$ ).

\begin{tabular}{lccccc}
\hline Layer $(\mathrm{m})$ & $0-0.14$ & $0.14-0.24$ & $0.24-0.54$ & $0.54-0.84$ & $0.84-1.20$ \\
\hline Cd $\left(\mathrm{mg} \mathrm{kg}^{-1}\right)$ & $1.13 \pm 0.010$ & $1.18 \pm 0.11$ & $1.29 \pm 0.15$ & $1.42 \pm 0.16$ & $1.32 \pm 0.22$ \\
\hline
\end{tabular}

and biological immobilization using a range of soil amendments, such as lime (Grant et al., 1999; Bolan et al., 2003a), zinc (Hassan et al., 2005) and phosphate (Bolan et al., 2003b) compounds, stabilized alkaline biosolid compost (Bolan et al., 2003c) and zeolite (Oste et al., 2002), phytoremediation ( $\mathrm{Su}$ and Wong, 2004) and the selection of rice varieties characterized by reduced uptake and translocation (Arao and Ae, 2003) may be useful for achieving this. Organic matter may play a dual role in influencing $\mathrm{Cd}$ availability in soil: low-molecularweight organic components serve as carriers of $\mathrm{Cd}$ in the soil solution, whilst high-molecular-weight organic components may be very effective at rendering Cd unavailable, functioning as a sink (McBride, 1995; Christensen and Haung, 1999). Some agronomic practices, i.e. soil dressing, soil amendment and paddy-field flooding, may reduce or increase $\mathrm{Cd}$ levels in grains. For example, if rice is cultivated under submerged conditions, the reducing redox potential results in a low correlation between the Cd content of the soil and grain (Daum et al., 2001). In 2003 and 2004, a field trial was performed in Italy, in a site located in the northern region (Po Valley), where rice cultivation is mostly located and where, according to previous unpublished studies, the Cd concentration in the produced brown rice grain exceeded the European regulatory limit. The aims of the study were to evaluate the origin of $\mathrm{Cd}$ in paddy field soils and the influence of some agricultural practices (soil treatment and water management) on $\mathrm{Cd}$ uptake by plants.

\section{MATERIALS AND METHODS}

The experimental trial was performed on a site in the locality of Rosate, $25 \mathrm{~km}$ south-west of Milan (Italy). The site was a field of 2 ha, cultivated in monosuccession for more than ten years. According to the Soil Taxonomy (Soil Survey Staff, 2006), the soil was classified as an Inceptisol Aquept. Forty-eight $25-\mathrm{cm}$ cores were collected at nodes of a $40 \times 20 \mathrm{~m}$ grid.

\section{Soil characteristics and atmospheric deposition}

Soil properties (Tab. I) were measured using official analytical methods (SSIS, 2000).

The mean $\mathrm{Cd}$ concentration in the topsoil - measured following nitric-hydrochloric acid digestion - is $0.96 \mathrm{mg} \mathrm{kg}^{-1}$,

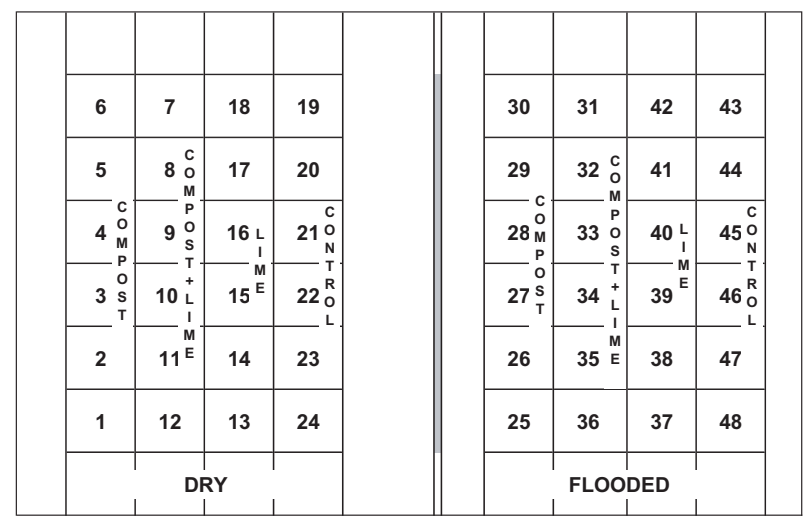

Figure 1. The experimental design: "dry" and "flooded" correspond to the main plots (type of water management), "compost", "compost + lime", "lime" and "control (untreated)" correspond to the subplots (type of soil amendment) and the gray squares numbered from 1 to 48 correspond to the collection points.

whereas the mean diethylenetriaminepentaacetate (DTPA)extractable fraction is $0.15 \mathrm{mg} \mathrm{kg}^{-1}$. The low standard deviation for these values indicates a reasonable soil homogeneity. In order to evaluate the possible geological origin of $\mathrm{Cd}$, the metal distribution through one soil profile was determined in samples taken from different layers, to a depth of 1.20 meters. The results of this analysis are shown in Table II.

The atmospheric contribution to $\mathrm{Cd}$ concentrations in the superficial soil layers was measured using a Bergerhoff instrument. Wet and dry deposits were collected on a monthly basis in 2003 and 2004, for two consecutive years. Cd concentration was determined using the method proposed by Thöni et al. (1999), by means of ICP-OES at $228.80 \mathrm{~nm}$ wavelength. The bulk deposition (mean of two years) was $1.53 \pm 0.72 \mu \mathrm{g} \mathrm{m}^{-2}$ $\mathrm{d}^{-1}$, corresponding to a supply of about $5 \mu \mathrm{g}$ per $\mathrm{kg}$ of topsoil.

\section{Experimental design and cultivation}

The rice selected for cultivation was Oryza sativa, var. Baldo. The experimental design (Fig. 1) comprised two main plots $(60 \times 124 \mathrm{~m}$ each $)$ corresponding to the different rice-sowing practices and field water-management strategies (dry-seeded with rotational irrigation and water-seeded with permanent flooding, respectively). The main plots were 
separated by an embankment. The distance between the test $\times$ dry subplot and the compost $\times$ flooded subplot was $30 \mathrm{~m}$. The mean concentration of total $\mathrm{Cd}$ was $1.01 \pm 0.06$ in the dry plot and $0.96 \pm 0.06$ in the flooded plot, and the mean concentrations of DTPA-extractable Cd were $0.13 \pm 0.02$ and $0.15 \pm 0.04$, respectively, these parameters, as well as the remaining soil characteristics, indicating a strong similarity of soil between the plots. The subplots $(15 \times 124 \mathrm{~m}$ each $)$ corresponded to four treatments (compost, compost and lime, lime and control (not treated with lime or compost)). In both years, amendments were applied to the selected subplots two months prior to sowing (and flooding) to avoid as much as possible any lateral migration among subplots. Compost was applied at $30 \mathrm{tha}^{-1}$ and lime $(80 \% \mathrm{CaO}$ and $15 \% \mathrm{MgO})$ at $1 \mathrm{tha}^{-1}$. Table III shows the mean results of $\mathrm{Cd}$ concentration in the compost and lime amendments as well as in the fertilizers, such as $\mathrm{KCl}$ and urea, used in all subplots indifferently (at 66 and $240 \mathrm{~kg} \mathrm{ha}^{-1}$, respectively). Each treatment was performed only following $\mathrm{Cd}$ analysis. Only in the case of "compost + lime" subplots were all the amendments and fertilizers used, with the maximum $\mathrm{Cd}$ supply among the subplots: $3 \mu \mathrm{g}$ per $\mathrm{kg}$ of topsoil.

Water management was conditioned by a co-operative distribution and, especially in 2003 , the very hot summer temperatures (Fig. 2) resulted in several 4-day periods of dryness between irrigation events.

\section{Sample collection and field measurement}

To individualize the collection points, each subplot was divided into eight square parts and the points were fixed in the middle of six squares, after having excluded those at the two ends. The six equidistant points (Fig. 2, numbered from 1 to 48), set $30 \mathrm{~m}$ apart, were georeferenced for the measurement of topsoil $\mathrm{pH}$, which was performed twice a year, at panicle initiation and heading, corresponding to the beginning of July and of August. At the same points, collection of plants (straw) and soil solution was realized three times a year during the trial, comprising the panicle initiation, heading and maturity, around the middle of October. During the growing period, 6 plants were collected from each collection point. In order to extract the soil solutions, cores of soil were collected at the same points. Cores collected under flooded conditions were kept under anaerobic conditions and dried under vacuum to avoid any oxidation or alteration of the redox status, which was negative at the moment of collection, due to anaerobic conditions typical of submersion. For samples collected under flooding conditions, anaerobiosis was preserved only in 2004: data from 2003 related to this plot were certainly misrepresentative. Samples collected under dry oxidized conditions in both years were dried according to official methods as well. Soil solution was extracted from all samples after grinding to $2 \mathrm{~mm}$, centrifugation for $30 \mathrm{~min}$ at $10000 \mathrm{rpm}$ (revolutions per minute) (water/soil: $2.5 / 1$ ) and filtration through a $0.45 \mu \mathrm{m}$ filter (Millipore).

Brown rice grain was collected from each subplot at the end of the experiment and mixed before analysis. At maturity, the produced dry biomass (mean of the subplots) was: grain
Table III. Cd content in soil amendments and fertilizers $\left(\mathrm{mg} \mathrm{kg}^{-1}\right)$ used in 2003 and 2004.

\begin{tabular}{lcc}
\hline Fertilizer & $\mathrm{Cd} 2003\left(\mathrm{mg} \mathrm{kg}^{-1}\right)$ & $\mathrm{Cd} \mathrm{2004}\left(\mathrm{mg} \mathrm{kg}^{-1}\right)$ \\
\hline Compost & $0.241 \pm 0.042$ & $0.36 \pm 0.10$ \\
Lime & $<0.31$ & $1.112 \pm 0.058$ \\
$\mathrm{KCl}$ & $<0.31$ & $2.5 \pm 1.5$ \\
Urea & $<0.31$ & $<0.31$ \\
\hline
\end{tabular}

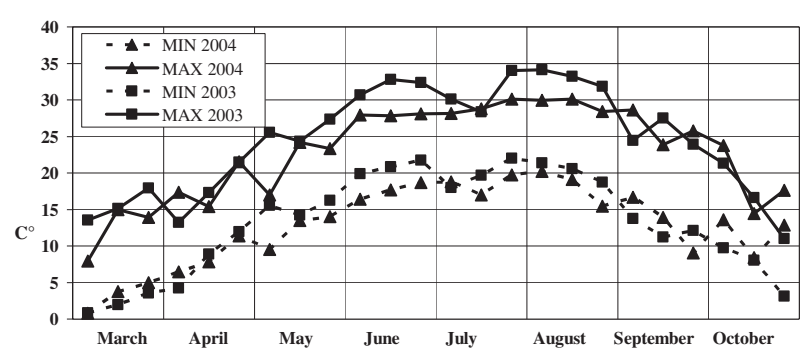

Figure 2. Variation in air temperature in the experimental site of Rosate (Italy) during 2003 and 2004.

$6780 \pm 540 \mathrm{~kg} \mathrm{ha}^{-1}$ and straw $8960 \pm 810 \mathrm{~kg} \mathrm{ha}^{-1}$ under dry conditions, and grain $6850 \pm 720 \mathrm{~kg} \mathrm{ha}^{-1}$ and straw $9450 \pm$ $370 \mathrm{~kg} \mathrm{ha}^{-1}$ under flooded conditions, indicating that the potential diluting effects caused by the interaction between yield and treatments, and between yield and $\mathrm{Cd}$ concentration, was not significant.

In 2004, $\mathrm{pH}$ and redox potential were monitored using 4 pairs of electrodes, permanently fitted at a depth of $30 \mathrm{~cm}$, in the control and lime subplots of the dry and flooded main plots, respectively.

Irrigation water was analyzed monthly. The mean $\mathrm{Cd}$ concentration was always below the limit of detection $(<1 \mathrm{ppb})$.

\section{Sample analysis}

The harvested plant samples were dried at $105{ }^{\circ} \mathrm{C}$ to constant weight, ground using a stainless steel grinder and digested by nitric acid microwave-assisted digestion (ETHOS, Milestone, FKV), performed using a modified US EPA SW 846 test method 3051 (Shute and Macfie, 2006). Analysis of $\mathrm{Cd}$ concentration was performed using Inductively-Coupled Plasma Optical Emission Spectrometry (ICP-OES, Spectro $\operatorname{CIROS}^{C C D}$ ). Soil solution Cd was measured by ICP-OES as well, after the extraction reported in the previous paragraph. Statistical analysis of the results was performed using SAS (SAS Institute, 1996).

\section{RESULTS AND DISCUSSION}

\subsection{Origin of $\mathrm{Cd}$ in soil}

The mean concentration of $\mathrm{Cd}$ in the superficial soil layer of the experimental field is $0.96 \pm 0.16 \mathrm{mg} \mathrm{kg}^{-1}$. The recorded data of the atmospheric depositions, as well as those of the supply by the irrigation water and applied amendments, suggest that any anthropic contribution is inconsistent. 
Table IV. Comparison of $\mathrm{pH}, \mathrm{Cd}$ concentration in soil solution and $\mathrm{Cd}$ in brown rice resulting from the interaction treatment and water management in 2003 and 2004 (mean of monthly measurements). Means with the same letters are not significantly different $(P<0.01)$ using the Duncan test.

\begin{tabular}{|c|c|c|c|c|c|c|}
\hline $\begin{array}{l}2003 \\
\text { Fertilizer } \times \text { water management }\end{array}$ & \multicolumn{2}{|c|}{ Soil solution $\mathrm{pH}$} & \multicolumn{2}{|c|}{$\begin{array}{l}\text { Soil solution } \mathrm{Cd} \\
\left(\mu \mathrm{g} \mathrm{L}^{-1}\right)\end{array}$} & \multicolumn{2}{|c|}{$\begin{array}{l}\text { Brown grain Cd } \\
\quad\left(\mathrm{mg} \mathrm{kg}^{-1}\right)\end{array}$} \\
\hline Compost $\times$ dry & 6.06 & $\mathrm{C}$ & 3.93 & $\mathrm{~A}$ & 0.25 & $\mathrm{~A}$ \\
\hline Control $\times$ dry & 6.03 & $\mathrm{C}$ & 5.27 & A & 0.25 & A \\
\hline Lime $\times$ dry & 6.24 & $\mathrm{BC}$ & 3.27 & A & 0.18 & B \\
\hline$($ Compost + lime $) \times$ dry & 6.40 & $\mathrm{AB}$ & 3.95 & A & 0.12 & $\mathrm{BCD}$ \\
\hline Compost $\times$ flooded & 6.18 & $\mathrm{BC}$ & 3.63 & A & 0.09 & $\mathrm{CD}$ \\
\hline Control $\times$ flooded & 6.13 & $\mathrm{C}$ & 4.23 & A & 0.14 & $\mathrm{BC}$ \\
\hline Lime $\times$ flooded & 6.25 & $\mathrm{BC}$ & 3.68 & $\mathrm{~A}$ & 0.07 & $\mathrm{D}$ \\
\hline$($ Compost + lime $) \times$ flooded & 6.51 & A & 3.95 & $\mathrm{~A}$ & 0.07 & $\mathrm{D}$ \\
\hline $\begin{array}{l}2004 \\
\text { Fertilizer } \times \text { water management }\end{array}$ & \multicolumn{2}{|c|}{ Soil solution $\mathrm{pH}$} & \multicolumn{2}{|c|}{$\begin{array}{l}\text { Soil solution } \mathrm{Cd} \\
\left(\mu \mathrm{g} \mathrm{L}^{-1}\right)\end{array}$} & \multicolumn{2}{|c|}{$\begin{array}{c}\text { Brown rice Cd } \\
\left(\mathrm{mg} \mathrm{kg}^{-1}\right)\end{array}$} \\
\hline Compost $\times$ dry & 6.71 & $\mathrm{C}$ & 5.68 & $\mathrm{AB}$ & 0.15 & A \\
\hline Control $\times$ dry & 6.50 & $\mathrm{D}$ & 5.94 & $\mathrm{~A}$ & 0.13 & A \\
\hline Lime $\times$ dry & 6.91 & $\mathrm{AB}$ & 4.93 & $\mathrm{AB}$ & 0.10 & B \\
\hline$($ Compost + lime $) \times$ dry & 6.91 & $\mathrm{AB}$ & 4.20 & B & 0.10 & B \\
\hline Compost $\times$ flooded & 6.86 & $\mathrm{~B}$ & 1.36 & $\mathrm{C}$ & 0.06 & $\mathrm{C}$ \\
\hline Control $\times$ flooded & 6.72 & $\mathrm{C}$ & 1.97 & $\mathrm{C}$ & 0.05 & $\mathrm{C}$ \\
\hline Lime $\times$ flooded & 6.87 & B & 1.00 & $\mathrm{C}$ & 0.05 & $\mathrm{C}$ \\
\hline$($ Compost + lime $) \times$ flooded & 7.05 & A & 1.14 & $\mathrm{C}$ & 0.05 & $\mathrm{C}$ \\
\hline
\end{tabular}

As cadmium is generally fairly immobile in the soil profile (Adriano, 2001), the investigation of the soil profile seems to be in agreement with this assertion. These findings conflict with what was reported by Singh and McLaughlin (1998), who found significant increases in soil Cd concentrations over time, due to atmospheric or agricultural inputs. Nonetheless, even if the concentration of total $\mathrm{Cd}$ in the investigated field is similar to what is reported for non-contaminated soils (Adriano, 2001), we found that the $\mathrm{Cd}$ content of the produced rice may still exceed the regulatory limit of $0.2 \mathrm{mg} \mathrm{kg}^{-1}$ (Fig. 4). For this reason, we tested the effect of flooding and soil amendment with lime and compost on the reduction of $\mathrm{Cd}$ by rice.

\subsection{Effect of water management}

Table IV shows that submersion was very useful for reducing the $\mathrm{Cd}$ concentration in rice grain in both years, with a great decrease ( $50 \%$ or more) in $\mathrm{Cd}$ assimilation compared with dry sowing. In 2004, the effect of flooding conditions was stronger than any of the treatments, with no significant differences between control and treatments, and concentration in grain of $0.06 \mathrm{mg} \mathrm{kg}^{-1}$ or less. This outcome depending on the water management could be due to a redox potential stable around $-400 \mathrm{mV}$ under flooded conditions and fluctuating from +300 to $-400 \mathrm{mV}$ under dry conditions (Fig. 3): under flooded conditions, corresponding to an Eh under $-200 \mathrm{mV}$, sulfate ions are reduced to sulfide ions that may form complexes with $\mathrm{Cd}$ and other metals, immobilizing them as sulfide salts (e.g. CdS, Gimeno-Garcìa et al., 1996), and sub-acid soils are generally neutralized (Sequi, 1989). In 2004, the variation in redox potential from oxidizing to reducing conditions was
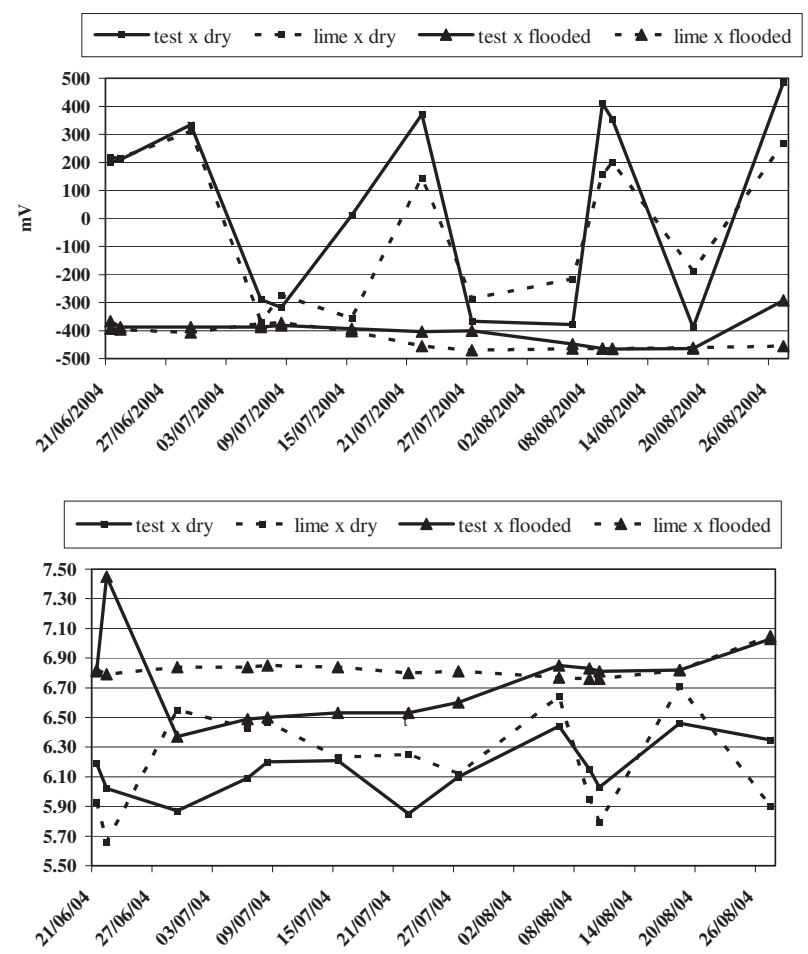

Figure 3. Modifications of (a) redox potential (Eh) and (b) $\mathrm{pH}$ in 2004 as affected by water management in control and lime subplots.

due to irrigation schedule, conditioned by a co-operative distribution of water, and produced a significant enhancement of the uptake of $\mathrm{Cd}$ by rice, with concentrations two times higher at least than for rice cultivated under submersion $(0.12$ versus 


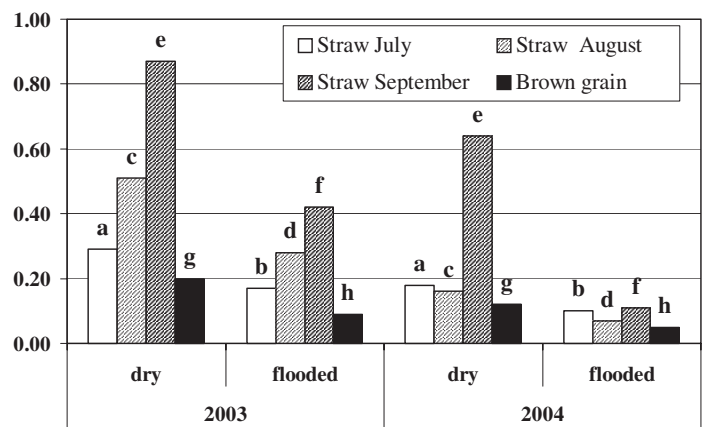

Figure 4. Cd content (mean value, $\mathrm{mg} \mathrm{kg}^{-1}$ ) in plants and brown rice, during the two experimental years. The graphs compare flooding and non-flooding conditions: means with the same letters in the same year are not significantly different $(P<0.01)$ using the Duncan test. The European regulatory limit for brown grain is $0.2 \mathrm{mg} \mathrm{kg}^{-1}$.

$0.05 \mathrm{mg} \mathrm{kg}^{-1}$, Fig. 4). These data partially confirmed what was reported by Daum et al. (2001), who showed that the alternation of submersion and drainage increased the $\mathrm{Cd}$ concentration in the whole plant and in rice grains compared with the usual strategy of continuous flooding until shortly before harvest. In 2003, the substantial uptake of $\mathrm{Cd}$, resulting in rice grain concentrations meanly in excess of the regulatory limit (Fig. 4), with values of $0.25 \mathrm{mg} \mathrm{kg}^{-1}$ in compost and control subplots for plants cultivated under dry conditions, is probably due to this alternation as well. Also, the high temperatures measured in this year (Fig. 2) could have improved what was observed: in effect, the concentration in brown rice generally increases in proportion to the amount absorbed by straw (Fig. 4), even if the data from 2004 show that accumulation over time is not necessarily linear. Some authors emphasized that the rice plant has no system for controlling the movement of cadmium into the aerian parts (Kashem and Singh, 2001) and others (e.g. Chino, 1981) noted the influence of the evapotranspiration rate on increasing both the lymphatic flux and the translocation of Cd. Differences in transpiration (and therefore in climate) could also explain differences in uptake over years.

The soil solution $\mathrm{pH}$ measured in the laboratory (Tab. IV) appears to reflect mostly the $\mathrm{pH}$ measured in the field (Fig. 3). Also, these data indicate that water management modified the effect of the amendments. For flooded conditions, the lack of fluctuation over time and the higher $\mathrm{pH}$ compared with dry conditions are typical consequences of a long-term submersion. Flooding usually produces an increase in the solubility of $\mathrm{Fe}$ and $\mathrm{Mn}$ and, consequently, an increase in immobilization of $\mathrm{Cd}$ by sorption in soil free sites provided by hydrous $\mathrm{Fe}$ and Mn oxides (Brown et al., 1989).

\subsection{Effect of lime and compost addition}

Soil treatments mainly affect soil $\mathrm{pH}$ (Fig. 3), although $\mathrm{pH}$ does not increase regularly over time and variations are smaller than $1 \mathrm{pH}$ unit. Nevertheless, the addition of compost and lime, as well as the addition of lime alone, and their effect on the $\mathrm{pH}$ revealed a good efficacy regarding the concentration of

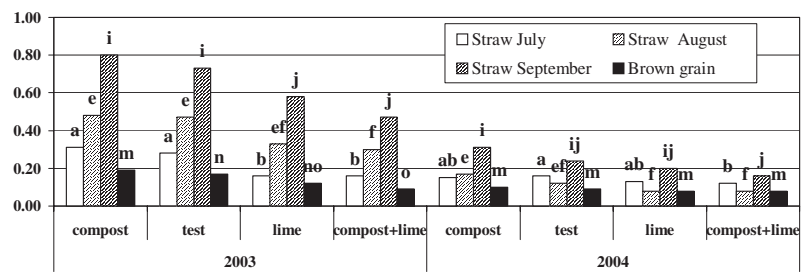

Figure 5. Rice Cd content (mean value, $\mathrm{mg} \mathrm{kg}^{-1}$ ) in plants and brown rice, during the two experimental years. The graphs compare treatments: means with the same letters in the same year are not significantly different $(P<0.01)$ using the Duncan test. The European regulatory limit for brown grain is $0.2 \mathrm{mg} \mathrm{kg}^{-1}$.

$\mathrm{Cd}$ in brown grain, in particular in 2003, for dry-seeded rice (Tab. IV). In fact, we observed a reduction of the bioavailability of soil $\mathrm{Cd}$, so that $\mathrm{Cd}$ concentrations in the produced rice were about $25 \%$ lower than for control and below the regulatory limit of $0.2 \mathrm{mg} \mathrm{kg}^{-1}$. Lime, dominated by variablecharge components, produces a rise in cation adsorption capacity (Bolan et al., 2003a) and also a precipitation of $\mathrm{Cd}$ as $\mathrm{CdCO}_{3}$ (Holm et al., 2003). Both of these processes reduce the availability of $\mathrm{Cd}$ to plants.

Compost application seems to be ineffectual on $\mathrm{Cd}$ availability (expressed as $\mathrm{Cd}$ concentration in solution or in grain): in both years the results do not show a clear effect of compost (Fig. 5 and Tab. IV).

This is consistent with the existing literature, which shows variable and contrary effects of compost organic matter on $\mathrm{Cd}$ uptake or solubility of soil Cd. For example, Kashem and Singh (2001) and Bolan et al. (2003c) found the application of humified organic matter (cow manure and biosolid compost) to decrease the total uptake of $\mathrm{Cd}$ by rice plants, due to an increased complexation of the metal in soil solution (Adriano, 2001). On the contrary, Antoniadis and Alloway (2002) and Christensen and Haung (1999) found that metals bound by soil components can be released into the soil solution following the decomposition of organic matter by soil microorganisms and the release of low-molecular-weight organic components. It has been observed (Grant et al., 1999) that this dual effect on metal availability to plants may be due to the variable composition of organic matter: low molecular fractions, such as hydrophilic bases, have a strong affinity towards forming soluble Cd complexes. Cd-DOC complexes are more labile in soil. The prevalence of high or low molecular fractions depends on the specific composition and on the aging of the considered organic soil amendment.

The application of compost with lime produced an effect on $\mathrm{Cd}$ assimilation by rice which was undetected in the case of application of compost alone and more similar to that of lime alone. The unexpected outcome of the compost and lime treatment could be due to an increased strength of the bond between $\mathrm{Cd}$ and organic matter.

In 2003, due to the incorrect conservation of samples from the flooded plot, we did not measure any difference between $\mathrm{Cd}$ in soil solution under aerobic and anaerobic conditions (Tab. IV). As a consequence, the calculation of correlation 
Table V. Effects of $\mathrm{Cd}$ concentration and $\mathrm{pH}$ of soil solution on $\mathrm{Cd}$ concentration in brown rice grain. Correlation coefficients (r) and their significance. $*$ and $* *$ indicate significance at $P<0.05$ and $P<0.01$ levels, respectively; n.s. $=$ not significant.

\begin{tabular}{lcc}
\hline Variable & Brown rice Cd & Significance \\
\hline Soil solution Cd July 2003 & 0.18 & n.s. \\
Soil solution Cd Aug. 2003 & 0.20 & n.s. \\
Soil solution pH July 2003 & -0.32 & $*$ \\
Soil solution pH Aug. 2003 & -0.36 & $*$ \\
Soil solution Cd July 2004 & 0.75 & $* *$ \\
Soil solution Cd Aug. 2004 & 0.57 & $* *$ \\
Soil solution pH July 2004 & -0.34 & $*$ \\
Soil solution pH Aug. 2004 & -0.44 & $* *$ \\
\hline
\end{tabular}

coefficients (Tab. V) was based only on values obtained under dry conditions.

In our study, the correlation between $\mathrm{Cd}$ concentration in brown rice and the $\mathrm{pH}$ of the soil solution was negative. We also found an increase in $\mathrm{Cd}$ in soil solution corresponding to a slight drop in $\mathrm{pH}$. In general, our results demonstrate the effect of soil amendments on the $\mathrm{pH}$ of soil solution and the effect of soil solution $\mathrm{pH}$ on $\mathrm{Cd}$ bioavailability in soil (Tab. IV). Increasing $\mathrm{pH}$ leads to the adsorption of $\mathrm{Cd}$ to soil organic matter and inorganic colloids (King, 1988; Simmons et al., 2005). Some authors (Kashem and Singh, 2001) reported that the affinity of $\mathrm{Cd}$ for soil sorption sites increased at high $\mathrm{pH}$ as $\mathrm{Cd}^{2+}$ forms $\mathrm{Cd}(\mathrm{OH})^{+}$by hydrolysis.

Although it is well known that the distribution of $\mathrm{Cd}$ between the soil solid phase and the soil solution is a key issue in assessing $\mathrm{Cd}$ assimilation (Holm et al., 2003), in our case the concentration in the soil solution was not always the only predictor of rice grain content. In effect, although there were differences in soil solution concentrations of $\mathrm{Cd}$ between the different water management techniques, these differences were either not significant or misrepresentative between the soil amendment treatments. In addition, the concentration of soluble Cd was greater in 2004, when uptake was lower (Tab. IV).

\section{CONCLUSION}

The soil studied here was non-polluted with a concentration of total Cd lower than $1 \mathrm{mg} \mathrm{kg}^{-1}$. Nevertheless, the content of $\mathrm{Cd}$ in the brown rice may exceed the regulatory limit of 0.2 $\mathrm{mg} \mathrm{kg}-1$ and could become hazardous to human health, particularly for children. Our results show that $\mathrm{Cd}$ concentration in rice is mainly affected by water management and amendments, both of which are strongly effective on redox potential and $\mathrm{pH}$, and consequently on $\mathrm{Cd}$ in soil solution. The anaerobic conditions, typical for flooding, are strongly effective at minimizing $\mathrm{Cd}$ concentrations in soil solution and in plant parts. Our results suggest that a redox potential below $-200 \mathrm{mV}$ should be preserved to improve the safety of rice. Lime treatment generated only a small increase in the $\mathrm{pH}$ of soil and soil solution, but it was very useful for reducing the accumulation of $\mathrm{Cd}$, especially if the soil was not submerged. This suggests that, if submersion is not possible, lime may be used to ensure the concentrations of $\mathrm{Cd}$ in rice are below the regulatory limit. Compost treatment, on the contrary, seems to be unsuccessful regarding the bioaccumulation of the investigated metal. Nevertheless, it should be noted that the synergism of lime and compost could increase the effect produced by lime alone. As the effect of humified organic matter, such as cow manure and biosolid compost, on the total uptake of $\mathrm{Cd}$ by rice plants depends on the composition of the organic matter and its interaction with soil properties, we recommend accurate selection and characterization of organic amendments. High temperatures, together with the alternation of submersion and drying, may substantially increase assimilation under dry conditions. Moreover, the dependence of $\mathrm{Cd}$ accumulation by rice on the climatic conditions in a particular year should not be overlooked. This work contributes to the understanding of agricultural techniques and of factors affecting $\mathrm{Cd}$ mobilization. This would aid in the development of guidelines for rice farmers. The employment of precautions useful for reducing the availability of $\mathrm{Cd}$ to rice could allow the production of high-quality rice crops, particularly in areas where rice contamination by $\mathrm{Cd}$ is a significant agricultural problem.

Acknowledgements: This research was financially supported by the Regione Lombardia and Ente Nazionale Risi within the projects CEREALOMB 2003 and RISOLOMB 2004.

\section{REFERENCES}

Adriano D.C. (2001). Trace elements in terrestrial environment; biogeochemistry, bioavailability and risks of metals, Springer, New York, p. 866.

Antoniadis V., Alloway B.J. (2002) The role of the dissolved organic carbon in the mobility of $\mathrm{Cd}, \mathrm{Ni}$ and $\mathrm{Zn}$ in sewage sludge-amended soils, Environ. Pollut. 17, 515-521.

Arao T., Ae N. (2003) Genotypic variations in cadmium levels of rice grain, Soil Sci. Plant Nutr. 49, 473-479.

Bolan N.S., Adriano D.C., Mani P.A., Duraisamy A. (2003a) Immobilization and phytoavailability of cadmium in variable charge soils. II. Effect of lime addition, Plant Soil 251, 187-198.

Bolan N.S., Adriano D.C., Naidu R. (2003b) Role of phosphorus in (Im)mobilizazion and bioavailability of heavy metals in the soilplant system, Rev. Environ. Contam. Toxicol. 177, 1-44.

Bolan N.S., Adriano D.C., Mani P.A., Duraisamy A. (2003c) Immobilization and phytoavailability of cadmium in variable charge soils. III. Effect of biosolid compost addition, Plant Soil 256, 231-241.

Brown P.H., Dunemann L., Schulz R., Marschner H. (1989) Influence of redox potential and plant species on the uptake of nickel and cadmium from soils, Pflanzenernahr. Bodenk., 85-91.

Chanmugathas P., Bollag J. (1987) Microbial mobilization of cadmium in soil under aerobic and anaerobic conditions, J. Environ. Qual. 16, $161-167$.

Chino M. (1981) Uptake-Transport of toxic Metals in Rice Plants. In Heavy Metal Pollution in Soils of Japan, in: Kitagishi K., Yamane I. (Eds.), Japan Scientific Societies Press, Tokyo, pp. 81-101.

Christensen T.H., Haung P.M. (1999) Solid phase cadmium and the reactions of aqueous cadmium with soil surfaces. In Cadmium in 
Soils and Plants, in: McLaughlin M.J., Singh B.R. (Eds.), Kluwer Academic Publishers, Dordrecht, pp. 65-96.

Council regulation (EC) (2001) No. 1881/2006, setting maximum levels for certain contaminants in foodstuffs, Off. J. Euro. Union L364, $5-24$.

Daum D., Bogdan K., Schenk M.K., Merkel D. (2001) Influence of the field water management on accumulation of arsenic and cadmium in paddy rice. In Plant Nutrition - Food Security and Sustainability of Agro-Ecosystems, in: Horst W.J. et al. (Eds.), Kluwer Academic Publishers, Dordrecht, pp. 290-291.

Gimeno-Garcìa E., Andrei V., Boluda R. (1996) Heavy metals incidence in the application of inorganic fertilizers and pesticides to rice farming soils, Environ. Pollut. 92, 19-25.

Grant C.A., Bailey L.D., McLaughlin M.J., Singh B.R. (1999) Management factors which influence cadmium concentration in crops. In Cadmium in Soils and Plants, in: McLaughlin M.J., Singh B.R. (Eds.), Kluwer Academic Publishers, Dordrecht, pp. 151-198.

Hassan M.J., Zhang G., Wu F., Wie K., Chen Z. (2005) Zinc alleviates growth inhibition and oxidative stress caused by cadmium in rice, J. Plant Nutr. Soil Sci. 168, 255-261.

Holm P.E., Rootzén H., Borggaard O.K., Moberg J.P., Christensen T. (2003) Correlation of cadmium distribution coefficients to soil characteristics, J. Environ. Qual. 32, 138-145.

John M.K., Van Laerhoven C.J., Chuah H.H. (1972) Factors affecting plant uptake and phytotoxicity of cadmium added to soils, Environ. Sci. Technol. 6, 1005-1009.

Kashem M.A., Singh B.R. (2001) Metal availability in contaminated soils: I. Effects of flooding and organic matter on changes in Eh, $\mathrm{pH}$ and solubility of $\mathrm{Cd}, \mathrm{Ni}$ and $\mathrm{Zn}$, Nutr. Cycl. Agroecosyst. 61, $247-255$.

King L.D. (1988) Retention of cadmium by several soils of the southeastern United States, J. Environ. Qual. 17, 246-250.

Liu J., Li K., Xu J., Liang J., Lu X., Yang J., Zhu Q. (2003) Interaction of $\mathrm{Cd}$ and five mineral nutrients for uptake and accumulation in different rice cultivars and genotypes, Field Crop. Res. 83, 271281

Lugon-Moulina L., Ryanb L., Doninia P., Rossia L. (2006) Cadmium content of phosphate fertilizers used for tobacco production, Agron. Sustain. Dev. 26, 151-155.
McBride M.B. (1995) Toxic metal accumulation from agricultural use of sludge: are USEPA regulations protective? J. Environ. Qual. 24, 5-18.

Oste L.A., Lexmond T.M., Van Riemsdijk W.H. (2002) Metal immobilization in soils using synthetic zeolites, J. Environ. Qual. 31, 813821.

SAS Institute (1996) SAS/STAT user's guide. Version 6, 4th ed., Vols. 1 and 2, SAS Inst., Cary, NC.

Sequi P. (1989) I suoli sommersi e il potenziale redox. In Chimica del Suolo, in: Sequi P. (Ed.), Patron Editore, Bologna, pp. 419-432.

Shute T., Macfie S.M. (2006) Cadmium and zinc accumulation in soybean: a threat to food safety? Sci. Total Environ. 371, 63-73.

Simmons R.W., Pongsakul P., Saiyasitpanich D., Klinphoklap S. (2005) Elevated levels of cadmium and zinc in paddy soils and elevated levels of cadmium in rice grain downstream of a zinc mineralized area in Thailand: implications for public health, Environ. Geochem. Health 27, 501-511.

Singh B.R., McLaughlin M.J. (1998) Cadmium in soils and plants. In Cadmium in Soils and Plants, in: McLaughlin M.J., Singh B.R. (Eds.), Kluwer Academic Publishers, Dordrecht, 1999, pp. 257267.

Soil Survey Staff (2006) Keys to Soil Taxonomy, 10th ed., USDA-NRC, Washington, $348 \mathrm{p}$.

SSIS, Soil Science Italian Society (2000) Metodi di analisi chimica del suolo, a cura di Pietro Violante. In Collana di metodi analitici per l'agricoltura, in: Sequi P. (Ed.), Franco Angeli, Bologna, p. 536.

Su D.C., Wong J.W.C. (2004). Selection of mustard oilseed rape (Brassica juncea L.) for phytoremediation of cadmium contaminated soil, Bull. Environ. Contam. Toxicol. 72, 991-998.

Suzuki S., Koyama H., Hattori T., Kawada T., Rivai I.F. (1988) Daily intake of cadmium: an ecological review. In Environmental and occupational chemical hazards, in: Sumino S. (Ed.), Natl. University Singapore and Kobe 8, pp. 205-217.

Thöni L., Krieg F., Siewers U. (1999) Technical note testing the Bergerhoff method to determine the bulk deposition loads of 49 elements, Atmos. Environ. 33, 337-344.

Welch R.M., Norvell W.A. (1999) Mechanisms of cadmium uptake, translocation and deposition in plants. In Cadmium in Soils and Plants, in: McLaughlin M.J., Singh B.R. (Eds.), Kluwer Academic Publishers, Dordrecht, pp. 125-144. 